\title{
The main challenges of cruise tourism and statistics of expectations in Georgia
}

\author{
Nino Abesadze ${ }^{1^{*}}$, Rusudan Kinkladze ${ }^{2}$, Maia Giorgobiani ${ }^{1}$, Natalia $_{\text {Robitashvili }}{ }^{3}$, and \\ Ketevan Chitaladze ${ }^{1}$ \\ ${ }^{1}$ Ivane Javakishvili Tbilisi State University, Department of Economic and Social Statistics 0177 \\ Tbilisi, Georgia \\ ${ }^{2}$ Georgian Technical University, Department of Business Administration, 0171 Tbilisi, Georgia \\ ${ }^{3}$ Batumi Shota Rustaveli State University, Department of Economics, 0160, Batumi, Georgia
}

\begin{abstract}
In parallel with global technologies and transformations, Georgia was intensively reviving and developing all types of tourism, the COVID-19 pandemic slowed the pace of rapid growth in the quantitative parameters of tourism, and then shifted tourism to a phase of economic uncertainty, leaving all types of tourism paralyzed. The main goal of the research was to identify the challenges facing cruise tourism and to develop recommendations for its development. The article discusses the importance of developing cruise tourism for the revival of tourism in Georgia. The potential of cruise tourism is characterized. According to the trends of the world, based on the annual report of the International Association of Cruise Lines for 2020, the statistics of cruises around the world are analyzed.We believe that educational projects should be started for tourism business owners, staff should be trained to give accurate recommendations regarding maritime cruises and COVID regulations, travel companies should be given the opportunity to take low-interest loans if necessary; State support for the promotion and development of tourism, including cruise tourism, is important.
\end{abstract}

\section{Introduction}

Along with digital technologies and transformations, all types of tourism were intensively revived and developed in Georgia, the COVID-19 pandemic slowed the rapid growth of quantitative tourism parameters, and then shifted tourism to a phase of economic uncertainty. That is why 2020, as in Georgia, as well as around the world, turned out to be a year of radical change and transformation of public relations, live contacts have been replaced by online platforms, people's lifestyles and rhythms have changed. Domestic tourism in anticipation of the revival regime is again in the dormant stage, which is why tourism in general still retains the status of passive viability. In view of all the above, the pandemic has significantly changed the parameters of Georgia's economic development, which has put business entities in a difficult situation. There is no doubt that the pandemic has had the greatest impact on the tourism sector both in terms of demand and supply [4].

\footnotetext{
* Corresponding author: nino.abesadze@tsu.ge
} 
However, in Georgia, as in other tourism countries, the basic statistical characteristics of tourism have changed significantly, expectations for tourism revival, especially domestic tourism, exist and they Is positive. This is confirmed by various studies, including those conducted by us, according to the results of which potential visitors are waiting for the stabilization of the epidemiological situation, are in the waiting mode, but have selected attractive tourist locations and types of tourist packages. At the same time, it should be noted that it is important for both international and domestic tourism markets to create high-quality tourism products and ensure a safe corridor and affordable air and land traffic [1].

For Georgia, tourism can be said to be a key to socio-economic progress due in part to its influence and an important resource for attracting investment to the country [8]. Tourism is one of the important sectors of the Georgian economy that has great potential. It is one of the most important sources of income and employment growth [3], but it is necessary to intensify measures to promote tourism and raise awareness of the country for the postpandemic period. Tourism revenue also increased significantly. As tourism develops, competition in the tourism industry grows. Countries are trying different types of traditional or innovative marketing PR campaigns to attract tourists. Practice shows that with good PR the results can be achieved very quickly [3].

It is known that visitors to the country come mainly by land and air. Cruise traffic capabilities are underestimated, so the scale of its use is uncertain. Clearly, increasing the intensity of cruise traffic will also contribute to the development of cruise, tours. To do this, first of all, it is necessary to pay attention to the pilot regions, where the flows of potential visitors can increase and impulse or strongly formed demands arise on cruise tours. To do this, it is necessary to ensure the diversity of cruise tourism products, even in the segment of the domestic tourism market, which should be accompanied by training to provide appropriate services to staff based on training, use of innovative methods of cruise tour business planning, etc. sh.

The main goal of the research was to identify the challenges facing cruise tourism and to develop recommendations for its development.

\section{Results}

Clearly, the use of digital technologies, which acquired new practical value during the Covid-19 pandemic, will play a major role in the development of tourism, including cruise tourism. Monotonous tourism packages were one of the main factors mentioned by tourists as a hindering factor in the development of tourism in Georgia. Clearly, digital transformation, as a synthesis of advanced digital technologies combining physical and digital systems, will be crucial to shaping and realizing demand for a country's diverse tourism product [5]. It can be boldly said that today, digital technologies are considered as a catalyst for the development of cruise tourism and consequently the growth of tourism in the country. Which is essential for the popularization, awareness raising and attractiveness of maritime, cruise tourism countries. Moreover, digital technologies are transforming the tourism industry and introducing new tourism products and services. Marine is a product that can become a characteristic niche of the Georgian tourism industry in terms of promotion and digital transformations, which is an inevitable process, as intensive advancement of travel companies' relationships with potential customers through online marketing, social networks and various applications. Therefore, it will be of great importance how Georgia's popularity will increase and its attractiveness coefficient in the digital world will increase.

Cruise tourism is less developed in Georgia, it can be said that it does not exist. However, it is one of the most demanding and fast growing sectors in the world. The 
increase in its attractiveness reinforces the trend of a systematic increase in its share in the structure of revenues from tourism.

It should be noted that cruise tourism is a very big business. So big, in fact, that according to a report by the International Cruise Lines Association, there has been a rapid growth in demand for cruise tours since 2010, for example, from 2011 to 2016, demand for cruises increased by $20.5 \%$. Global cruise passengers reached 25.8 million in $2017,27.2$ million in 2018, and more than 32 million in 2020. The secret of the attractiveness of cruise tours is due to the fact that tourists are satisfied with the structure of the services received during the tours, with a wide range of opportunities for self-realization for leisure, offering the best and most comprehensive environment for travel lovers, etc. Such an attitude towards cruise tours was formed when analyzing the databases obtained from customer surveys. "Respondents note that more people are more open on the cruise than ever before," and that the cruise is one of the most exciting travels with families. It is the best and most comprehensive trip for those who want to travel more and more [7].

It is true that Georgia has excellent natural resources for the development of cruise tourism, but natural values alone are not enough to form new cruise-related tourism products and, moreover, to market them. It is necessary to support the state to travel companies, their wide promotion, based on various advertisements, banners, information meetings, etc.

In addition, it should be noted that cruise tourism, such as river cruises, may develop in Georgia. Large rivers of the country according to the Caspian and Black Sea basins: Mtkvari $1364 \mathrm{~km}$. Including $351 \mathrm{~km}$ in Georgia, flows in Samtskhe-Javakheti, Shida Kartli and Kvemo Kartli, Alazani, respectively $407 \mathrm{~km}$, in Georgia $390 \mathrm{~km}$, flows Kakheti, Enguri, with a total length of $213 \mathrm{~km}$, including $213 \mathrm{~km}$ in Georgia, [10] flows in Samegrelo-Zemo Svaneti, Abkhazia, Rioni with a total length of $333 \mathrm{~km}$, respectively 333 $\mathrm{km}$ in Georgia, flows in Racha-Lechkhumi-Kvemo Svaneti and Imereti, Iori, which is 320 $\mathrm{km}$ long, including $183 \mathrm{~km}$ in Georgia, flows in Mtskheta-Mtianeti and Kakheti, Khrami is $210 \mathrm{~km}$ long, its length in Georgia $187 \mathrm{~km}$, flows in Kvemo Kartli, etc. [9]. Can be actively used in the direction of tourism. It is true that it is the practice of mini-tours to walk on them, but the existence of perfect packages will increase the possibilities of using the rivers for tourism purposes. These types of tourism products are quite popular in Europe. Therefore, it is essential to share international experience and train tour operators on how to host a river-cruise night. The popularity of such tours is facilitated by the use of many new modernized vessels in this direction, which, given the perfection of the relevant infrastructure, has become a source of customer attraction and growth trends in cruise tourism.

According to the 2020 report of the International Cruise Lines Association, there are a total of 55 cruise lines in the world, including $98 \%$ of ocean, river and special cruises, 400 executive partners, these are major suppliers and cruise line partners, including ports and destinations, ship development, delivery and business In the direction of services. Cruise tours are served by 15,000 travel agencies and 53,000 member agencies worldwide.

It is true that Georgia has excellent natural resources for the development of cruise tourism, but natural values alone are not enough to form new cruise-related tourism products and, moreover, to market them. It is necessary to support the state to travel companies, their wide promotion, based on various advertisements, banners, information meetings, etc. According to the same report, it was engaged in cruise tourism alone and 32 million people worldwide used its services and as a diagram 1- From 2009 to 2020, the number of cruise tourists increased by an average of $5 \%$ each year. 


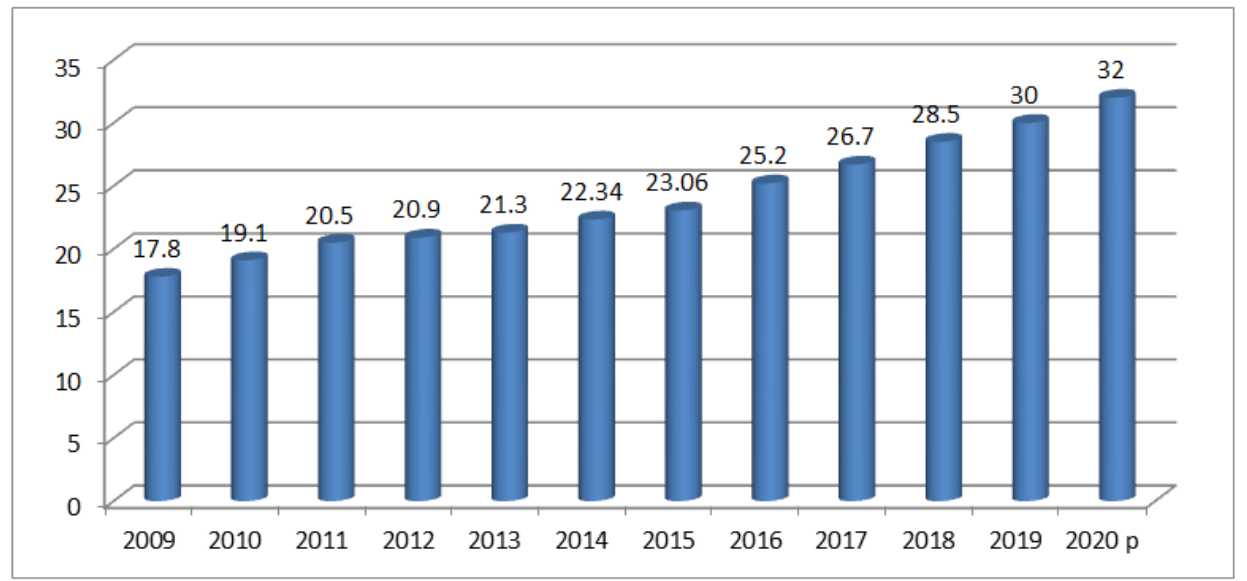

Fig. 1. Global Ocean Cruise Passengers (In Millions) [6].

You are probably wondering which locations are attractive for customers if they are interested in cruise tourism.

According to a 2020 report by the International Cruise Lines Association, 32\% of all cruise lines came from the Caribbean, 17\% from Mediterranean Europe, 5\% from Alaska, $5 \%$ from China, and so on. It should be noted that according to the 2018 report, the list of popular locations was unconditionally led by Alaska, followed by the Caribbean, the Mediterranean, Canada, Australia and others. Sh. Regions.

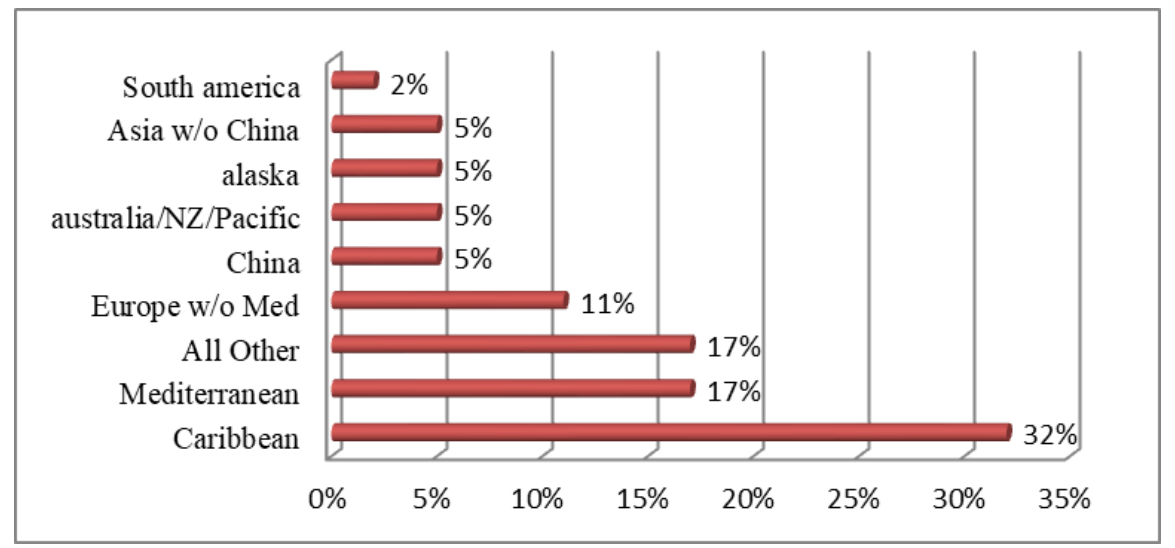

Fig. 2. Cruise Line Deployment By Region, \% [6].

Where Are Passengers Coming From?

A 2020 report by the International Cruise Lines Association shows that interest rates on cruise tours were high in North America, Western Europe, Asia, Australia and New Zealand. 


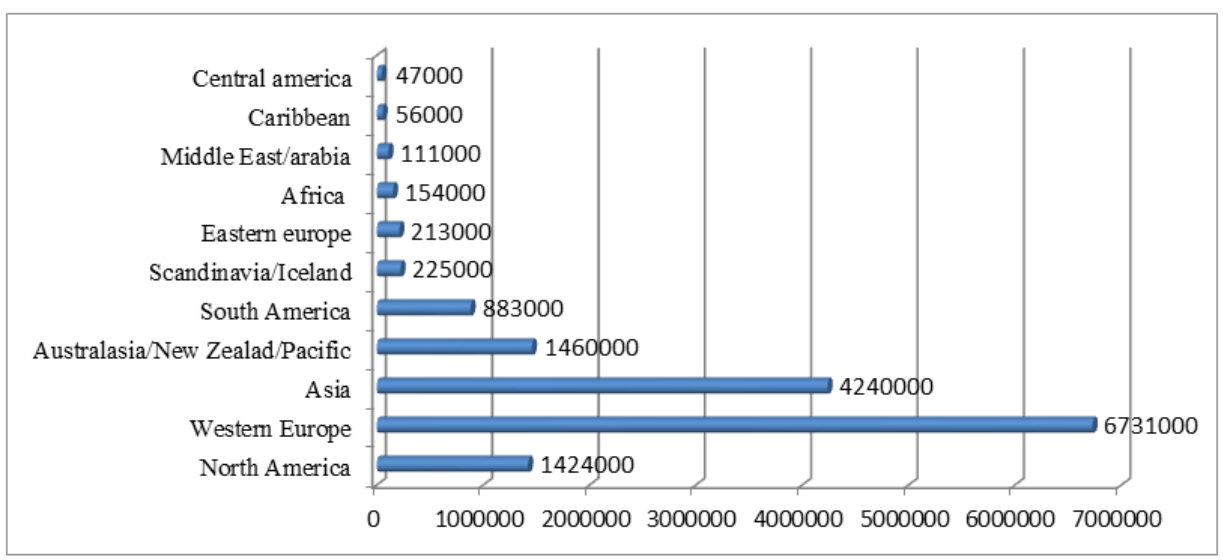

Fig. 3. Distribution of tourists by regions [6].

As it turned out, attractive cruise locations are headed by the Caribbean / Bermuda / Mexico, the list of popular destinations is Mediterranean Europe, Alaska. Canada Australia, New Zealand, North America, China, and so on. Sh.

It should be noted that according to the Cruise Lines International Association 2020 report, $82 \%$ of cruise tourism customers have expressed a desire to use the cruise service again during the next vacation.

Perhaps you are wondering what is the cost of cruise tourism per capita per capita? According to the same report, the expenses incurred by one tourist before boarding the ship amounted to 376 USD, while during the cruise itself 101 USD.

Of the countries of the former Soviet Union, most cruise tourism was developed by the Baltic states. Take, for example, the Riga-Stockholm, Stockholm-Riga cruise line, which is growing in popularity not only for its attractive package structure but also for its price. It is possible to buy a passenger ticket for one por for just 50 euros. The tourist is given the opportunity to spend the whole full day in Stockholm, with the prospect of sightseeing. This is a 2-night cruise Riga-Stockholm-Riga (or vice versa Stockholm-Riga-Stockholm). Allowing tourists to travel with a tour guide and guide, transfer from both city center to the port, all conditions on board are created for tourists to feel comfortable and enjoy the entertainment center, restaurants and on-board bar. Additional tax cases are also included in the offer for a car tour of Stockholm with the help of a guide.

Why not organize such short-term tours from Georgia, even to Turkey or Azerbaijan?

The tourism potential of our country, the fascinating nature, the potential of water resources, the infrastructure of tourist locations create the preconditions for cruise tourism to take a worthy place in the strategy of future tourism development.

Various studies conducted in Georgia, including our own, show that the population has expectations for the development of tourism. Today, the main indicator of tourism revival is undoubtedly domestic tourism. With the Google Drive document, we conducted a survey of the population of Georgia to identify popular tourism products and attractive locations. As the results of the research showed, the population is attracted to mountain, eco, adventure tours. $28 \%$ of respondents expressed dissatisfaction with the lack of opportunities to offer cruise tours in the country, both in terms of domestic tourism, especially international outbound tourism. This indicates that as a result of proper support and transformations, it is possible to modernize Georgian tour products in accordance with new, modern requirements.

An interesting picture was revealed during the analysis of the persons accompanying the trip. As the data show, the number of respondents who want to travel with relatives and 
loved ones increases with age, while the share of those willing to travel with friends is higher in the case of younger age groups. It should be noted that the younger generation is most attracted to adventure tourism, and the number of people wishing for a cruise tour increased with age.

In the case of domestic tourism, as the survey showed, in $2020,60.5 \%$ of respondents had a history of domestic tourism. A large proportion of them $(58 \%)$ traveled with friends and relatives, $-14 \%$ alone, and $11 \%$ of respondents with family members.

For almost $60 \%$ of domestic tourism travelers, the purpose was to relax, have fun and recreate. There were, for $14 \%$, visiting relatives and loved ones. For $16 \%$ treatment and health improvement, for $10 \%$ professional activities. As we can see, the main goal of domestic tourism in Georgia is related to recreation. Therefore, their potential can be easily used in organizing river and sea cruises. However,

The majority of internal visitor respondents $(63 \%)$ prefer the hotel as the most popular accommodation, $8 \%$ - hostel, $10 \%$ - guest house, $11 \%$ - relative's house. One of the most important factors in the effectiveness of cruise tourism is the good infrastructure tailored to the onboard customers. If the quality and price of the service are consistent, the promotion of comfortable room offerings will become a catalyst for the development of cruise tourism.

When analyzing the costs for them, $28 \%$ of respondents said that they would spend up to 500 GEL while traveling, $22 \%$ - up to 1000 GEL and $50 \%$-up to 1500 GEL. When asked which territorial location you would choose to travel to tomorrow, $31 \%$ of respondents preferred to spend their vacation at the sea, $12 \%$ would go to visit the colorful lakes of Abudelauri, rafting in Pasanauri turned out to be attractive for $18 \%$, Dashburi for $9 \%$.

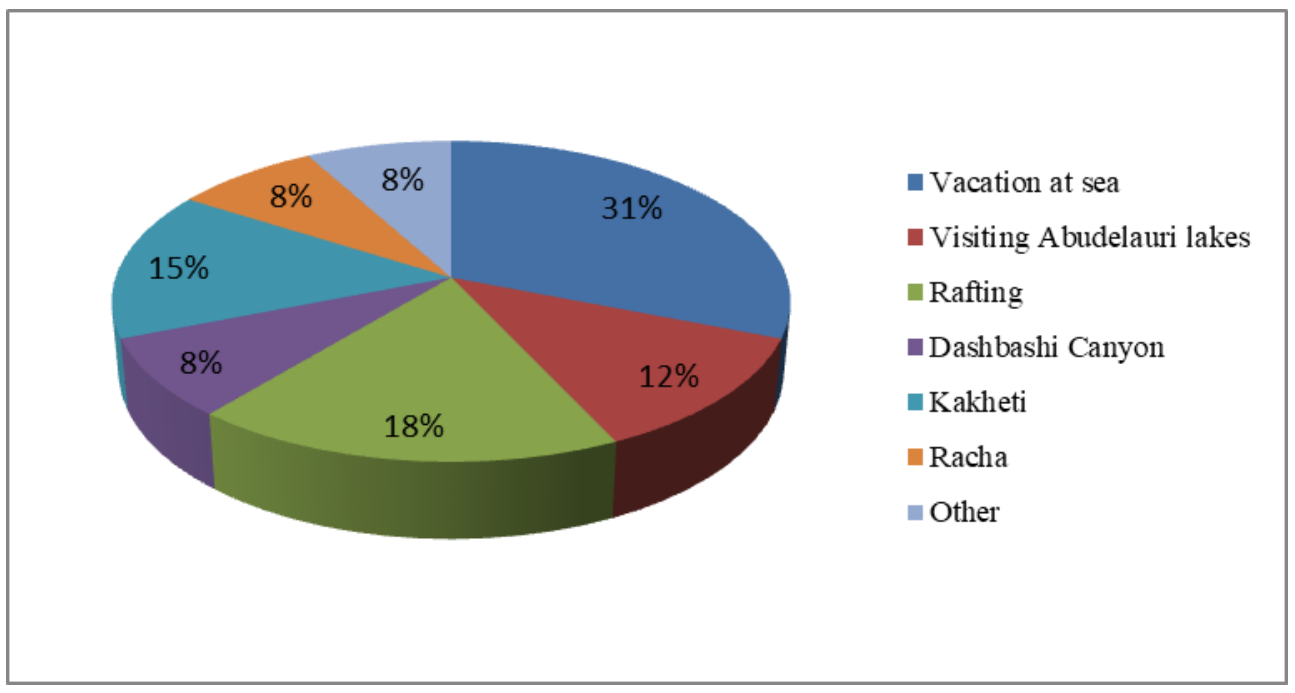

Fig. 4. Distribution of respondents according to attractive locations- $\%$.

Water-associated locations have been named as preferred locations. This indicates that if well-packed river and sea cruise tours enter the Georgian tourism market, there will most likely be a high level of interest from Georgian residents in both international outbound and domestic tourism.

It is also a fact that the survival of tourism at this stage should be at the expense of activating domestic tourism. It is true that international visitors started arriving in Georgia on February 1, 2021, but according to official statistics, reaching the level reached by 2020 will not be possible in the near future. 
That is why the importance of activating domestic tourism is growing. Along with the traditional, existing tourist packages in the tourist market, new products, which were foreign to Georgian residents, including cruise tours, must appear.

Based on all the above, it can be said that tourism in Georgia is waiting for revival. The strict regulations caused by the pandemic are slowly opening up, creating a stimulating base for domestic tourism activation with the necessary recommendations in mind. Here it will be crucial to inform the population, increase, provide a safe environment, use virtual tour applications, modern advances in digital technology, etc.

\section{Conclusion}

In conclusion, we can formulate the main recommendations for the development of cruise tourism in Georgia:

- Georgia should become a safe destination for visitors;

- It is necessary to provide safe and secure cruise traffic along with affordable and safe air and land traffic, which is one of the catalysts for increasing the number of tourists;

- In order to activate cruise tourism, it is necessary to increase the interest in domestic tourism;

- Educational projects should be started for tourism business owners, staff should be trained to give accurate recommendations regarding cruises and COVID regulations.

- Travel companies, if necessary, should be given the opportunity to take low-interest loans;

- It is important to support the state for the promotion and development of tourism, including cruise tourism;

- It is necessary to have thematic meetings (including online mode), news exhibitions, videos, information banners, virtual tours, applications with built-in voice guide, etc. sh.

\section{References}

1. Abesadze, N., Abesadze, O., \& Amanova, L. (2020). Trends Of The Attractiveness Of Azerbaijan Tourists In Georgia. Economic and Social Development. Book of Proceedings, 1(4), 55th International Scientific Conference on Economic and Social Development. Baku.

2. Abesadze, N., Abesadze, O., \& Amanova, L. (2020). Trends In The Growth Of Tourist Flows From Azerbaijan To Georgia. The Journal Of Economic Sciences: Theory And Practice, 77(1).

3. Abesadze, N., Kinkladze, R., Paresashvili, N., Cjitaladze, K., \& Meoshvili, S. (2020). Trends of increases of Georgia's attractiveness for EU Countries. Brussels, Belgium.

4. Abesadze, O. (2020). Post-pandemic tourism expectations and development trends in Georgia. Economics, 10-12.

5. Amanova, L., Abesadze, N., \& Abesadze, O. (2021). The Importance of digital technologies in the revival of tourism in Georgia and Azerbaijan. Baku. Azerbaijan.

6. Cruise Lines International Association. (2020). State Of The Cruise 2020 Industry Outlook. https://cruising.org

7. Cruise Lines International Association (n.d.). Travel agent cruise industry outlook. https://cruising.org

8. Tikishvili, M., Giorgobiani, M., \& Shonia, Z. (2014). Ecotourism and its infrastructure development prospects based on statistical calculations in EXCEl. Batumi.

9. Reading Ladder (n.d.). http://reading.ge/ka/books-by-level/192-saqartvelos-mdinareebi

10. Saqartveloi (2015). Rivers of Georgia. https://saqartveloi.blogspot.com/ 